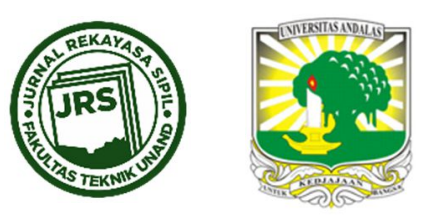

\title{
KAJIAN NUMERIK PERILAKU SEISMIK LINK GESER PADA SISTEM STRUKTUR BAJA TAHAN GEMPA TIPE EBF
}

\author{
YURISMAN $^{1}$, BUYUNG ARMY $^{1}$, DESNILA SARI ${ }^{1}$, MAIYOZZI CHAIRI $^{2}$ \\ ${ }^{1}$ Jurusan, Teknik Sipil Politeknik Negeri Padang, Padang, Sumatera Barat Indonesia \\ ${ }^{2}$ Mahasiswa Doktoral, Jurusan Teknik Sipil Universitas Andalas, Padang, Sumatera Barat, Indonesia \\ *Corresponding author: $ه$ yurisman_pdg@yahoo.com
}

Naskah diterima : 3 Oktober 2021. Disetujui: 14 Desember 2021

\begin{abstract}
ABSTRAK
Artikel ini memaparkan hasil studi numerik terhadap perilaku link geser (shear link) pada sistem struktur baja tahan gempa tipe Eccentrically Braced Frame $(E B F)$. Rangka baja berpengaku eksentrik $(E B F)$ mempunyai kekakuan elastik yang sangat baik dibawah pembebanan lateral sedang dan mempunyai daktilitas yang tinggi saat dibebani beban gempa yang besar. Dibawah kondisi pembebanan ekstrim perilaku inelastik direncanakan untuk ditahan oleh Link. Kinerja dari system struktur EBF sangat tergantung dari perilaku elemen link yang berfungsi sebagai sekring pada sistem struktur tersebut. Dalam kajian ini telah diteliti terhadap beberapa parameter yang berpengaruh secara signifikan terhadap perilaku seismik elemen Link. Kajian ini bertujuan untuk mendapatkan Link dengan kinerja seismic (kekuatan, kekakuan, daktilitas dan dissipasi energi) yang lebih tinggi dibandingkan dengan link standar AISC sehingga diharapkan pada akhirnya akan mendapatkan sstem EBF dengan kinerja yang lebih baik. Kinerja Link diukur dalam nilai kekuatan (strength), kekakuan (stiffness), daktilitas (ductility) serta kemampuan Link dalam melakukan dissipasi energi. Kajian dilakukan secara numerik dengan menggunakan program applikasi Patran_Nastran dimana Link dimodelkan sebagai balok yang terpisah dari system EBF (sub assembly) yang dikekang pada kedua ujungnya sementara pada salah satu ujung tersebut diberikan beban perpindahan secara siklik dan monotonik dengan kontrol perpindahan (displacement control). Beberapa parameter yang diteliti mencakup parameter penampang, modifikasi terhadap pengaku dibagian badan. Parameter penampang yang diteliti adalah yang terkait dengan kelansingan penampang $(\mathrm{h} / \mathrm{tw}, \mathrm{bf} / \mathrm{tf})$ sedangkan modifikasi terhadap pengaku badan dilakukan dalam bentuk pemasangan pengaku dalam arah diagonal. Hasil penelitian menunjukkan bahwa parameter kelansingan badan $(\mathrm{h} / \mathrm{tw})$, kelansingan sayap (bf/2tf), dan penempatan pengaku secara diagonal mempunyai pengaruh yang signifikan terhadap kinerja Link, sedangkan jarak plat pengaku lateral tidak mempunyai pengaruh yang berarti. Hasil analisis terhadap perilaku seismik Link geser dinyatakan dalam bentuk kurva beban vs perpindahan. Dari hasil kajian ini dapat disimpulkan bahwa untuk mendapatkan Link dengan kinerja yang lebih baik dapat dilakukan dengan cara modifikasi terhadap penampang dan melakukan rekayasa terhadap geometrik pengaku badan (pengaku vertikal dan diagonal).
\end{abstract}

Kata kunci : Link Geser, kekuatan (strength), kekakuan (stiffness), daktilitas (ductility), dissipasi energi 


\section{PENDAHULUAN}

Penelitian penelitian terhadap sistem $E B F$ lebih difokuskan terhadap bagaimana perilaku Link dalam sistem $E B F$ tersebut. Dari penelitian-penelitian sebelumnya telah disimpulkan bahwa kinerja sistem $E B F$ sangat tergantung pada perilaku elemen Link yang berperan sebagai elemen pendissipasi energi (energy dissipator) gempa yang masuk pada struktur. Beberapa parameter yang berpengaruh secara signifikan terhadap kinerja elemen link adalah : panjang link, tebal penampang, jarak pengaku, dan tebal pengaku (Engelhardt \& Popov, 1992; Kasai \& Popov, 1986; Malley \& Popov, 1984; Ricles \& Popov, 1989). Dan dari hasil-hasil penelitian penelitian tersebut juga telah disimpulkan bahwa : link pendek dianggap paling efektif dalam melakukan proses dissipasi energi gempa yang masuk pada struktur. Standar AISC (American Institute of Steel Construction) 2005 (American Institute of Steel Construction, 2005) menetapkan nilai rotasi inelastik rencana untuk link geser sebesar 0,08 radian dan untuk link panjang sebesar 0,02 radian. Besarnya sudut deformasi pada link pendek dapat menimbulkan kerusakan-kerusakan pada elemen-elemen non struktural, dan pada sisi lain link panjang mempunyai sudut deformasi yang lebih kecil dari link pendek tetapi mempunyai nilai daktilitas dan kemampuan dissipasi energi yang lebih rendah.

Rangka berpengaku eksentrik $(E B F)$ adalah suatu sistem struktur penahan gaya seismik yang dianggap baik karena mempunyai kapasitas yang merupakan kombinasi antara daktilitas yang besar dan kekakuan yang tinggi (Ghobarah \& Ramadan, 1991). Sistem EBF menahan beban lateral melalui kombinasi dari aksi rangka dan truss. Dengan kata lain dapat dilihat sebagai sistem hybrid antara Moment Resisting Frame (MRF) dan Concentrically Braced Frame $(C B F)$. EBF menyediakan daktilitas yang tinggi seperti $M R F$ melalui proses plastifikasi yang terjadi pada Link, dan pada saat yang sama memberikan perilaku kekakuan elastis yang tinggi seperti yang diberikan oleh CBF. Elemen struktur yang dinamakan Link berperan sebagai sekring (fuse) pada struktur EBF yang direncanakan berperilaku inelastis di bawah kondisi pembebanan seismik ekstrim.

Dalam beberapa penelitian yang pernah dilakukan sebelumnya, peneliti telah mencoba untuk melakukan inovasi terhadap model geometrik elemen Link, yaitu dengan menggunakan pengaku diagonal pada bagian badan untuk link dengan profil WF dan telah dipublikasikan dalam jurnal nasional terakreditasi (Yurisman et al., 2010b) dan internasional (Yurisman et al., 2010a), juga telah dipublikasikan dalam beberapa prosiding seminar nasional / konferensi teknik sipil. Berdasarkan hasil penelitian tersebut diketahui bahwa dengan menggunakan pengaku diagonal dapat meningkatkan kinerja link geser dalam hal : kekuatan, kekakuan dan dissipasi energi dibandingkan dengan link tanpa pengaku diagonal serta didapatkan juga disain yang lebih ekonomis.

Studi studi selanjutnya yang dilakukan 5 (lima) tahun terakhir ini menunjukkan perkembangan baru terhadap perlaku elemen Link diantaranya yang dilakukan oleh : Kurdi, dkk tentang pengaruh residual stress terhadap perilaku Link (Kurdi et al., 2017). Dmytri Volynkin, dkk meneliti tentang jarak pengaku (Volynkin et al., 2019). R.Chacon, dkk meneliti tentang Link dengan material terbuat dari Stainlees steel (Chacón et al., 2019), dan oleh peneliti peneliti lainnya.

Dalam artikel ini peneliti mencoba memaparkan hasil studi tentang perilaku seismik link geser dengan melakukan kajian terhadap pengaruh tekuk lokal, modifikasi pengaku badan dan penampang terhadap kinerja Link geser. Indikator kinerja Link geser yang diteliti dalam penelitian ini adalah : kekuatan (strength), kekakuan (stiffness), daktilitas (ductility) dan kemampuan dalam dissipasi energi. 
Link adalah salah satu elemen yang terdapat dalam sistem EBF yang berperilaku sebagai balok pendek yang pada kedua sisinya bekerja gaya geser dengan arah yang berlawanan serta momen lentur yang diakibatkan oleh gaya geser tersebut. Karena gaya geser yang berlawanan arah maka momen yang bekerja pada ujung-ujung elemen link mempunyai besar dan arah yang sama seperti yang diperlihatkan dalam Gambar 1. Plastifikasi yang terjadi pada elemen link disebabkan oleh kedua gaya tersebut di atas, oleh karena itu maka perilaku elemen link secara garis besar dapat dibedakan menjadi dua tipe yaitu : 1) link lentur (moment link) dan 2) link geser (shear link). Link dikatakan sebagai link geser apabila kelelehan yang terjadi disebabkan oleh gaya geser, dan dikatakan sebagai link lentur apabila kelehan yang terjadi disebabkan oleh momen lentur.

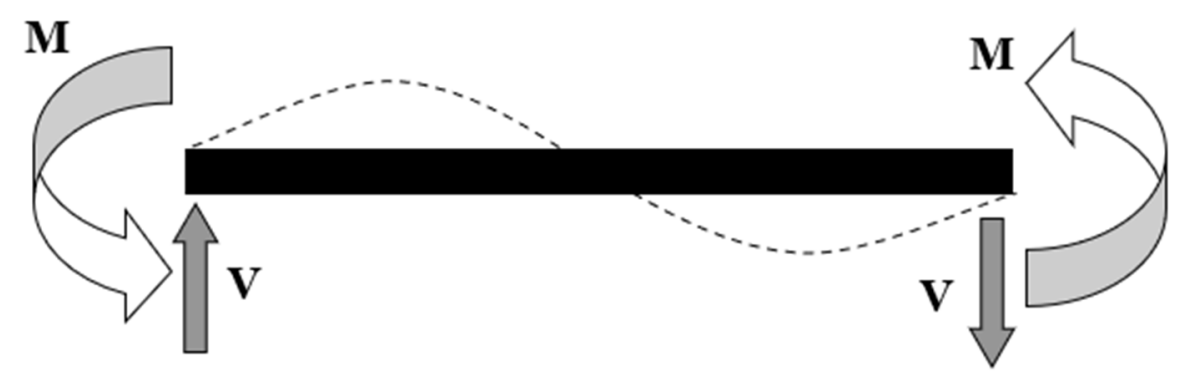

Gambar 1. Gaya - gaya pada elemen link (yurisman, dkk. 2010)

Deformasi paska leleh sebuah balok link disebabkan oleh : kelelehan geser, kelelehan lentur atau kombinasi dari keduanya. Dengan menggunakan sebuah model analitis sederhana dapat ditentukan suatu batasan yang tepat antara mekanisme lentur dan mekanisme geser. Batasan ini dapat diGambarkan dengan menggunakan sebuah bentangan geser yang leleh secara serempak dalam kondisi lentur dan geser. Perbandingan perilaku elemen link dalam tiga kondisi keruntuhan (geser, lentur dan kombinasi geser dan lentur) diperlihatkan dalam Gambar 2.

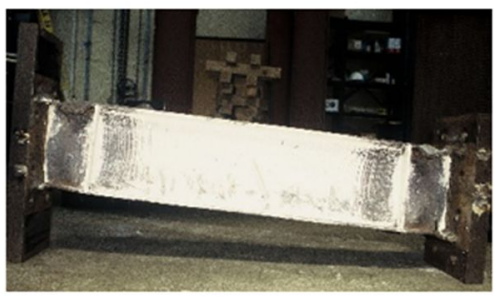

(a)

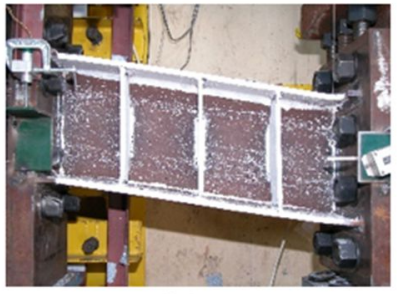

(b)

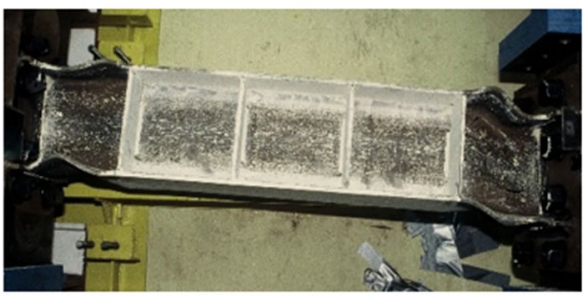

(c)

Gambar 2. Perbandingan perilaku keruntuhan link akibat : (a) lentur, (b) geser dan (c) kombinasi lentur dan geser

\section{METODA PENELITIAN}

Metode yang digunakan dalam penelitian ini adalah kajian secara numerik dengan menggunakan pemodelan elemen hingga (finite element), dengan bantuan perangkat lunak (software) Patran_Nastran versi student 2020. Penelitian ini menganalisa perilaku link geser yang terbuat dari profil baja IWF 200.100.5,5.8 yang panjangnya $400 \mathrm{~mm}$, perilaku balok baja yang diamati dalam penelitian ini adalah perilaku yang terkait dengan respon balok tersebut terhadap gaya gempa yang bekerja pada struktur. 
Beberapa parameter seismik yang diamati dalam studi parametrik ini mencakup kekuatan (strength), kekakuan (stiffenes), daktilitas (ductility) dan kemampuan dalam diisipasi energi. Semua parameter seismik tersebut mengGambarkan bagaimana kinerja balok dalam merespon gaya gempa yang masuk pada struktur. Link dikatakan mempunyai kinerja yang baik dalam merespon gaya gempa apabila semua parameter tersebut mempunyai nilai nilai yang sesuai standar.

Bagan alir yang diperlihatkan dalam Gambar 3 menunjukkan langkah langkah dalam kajian numerik sesuai dengan tujuan yang hendak dicapai.

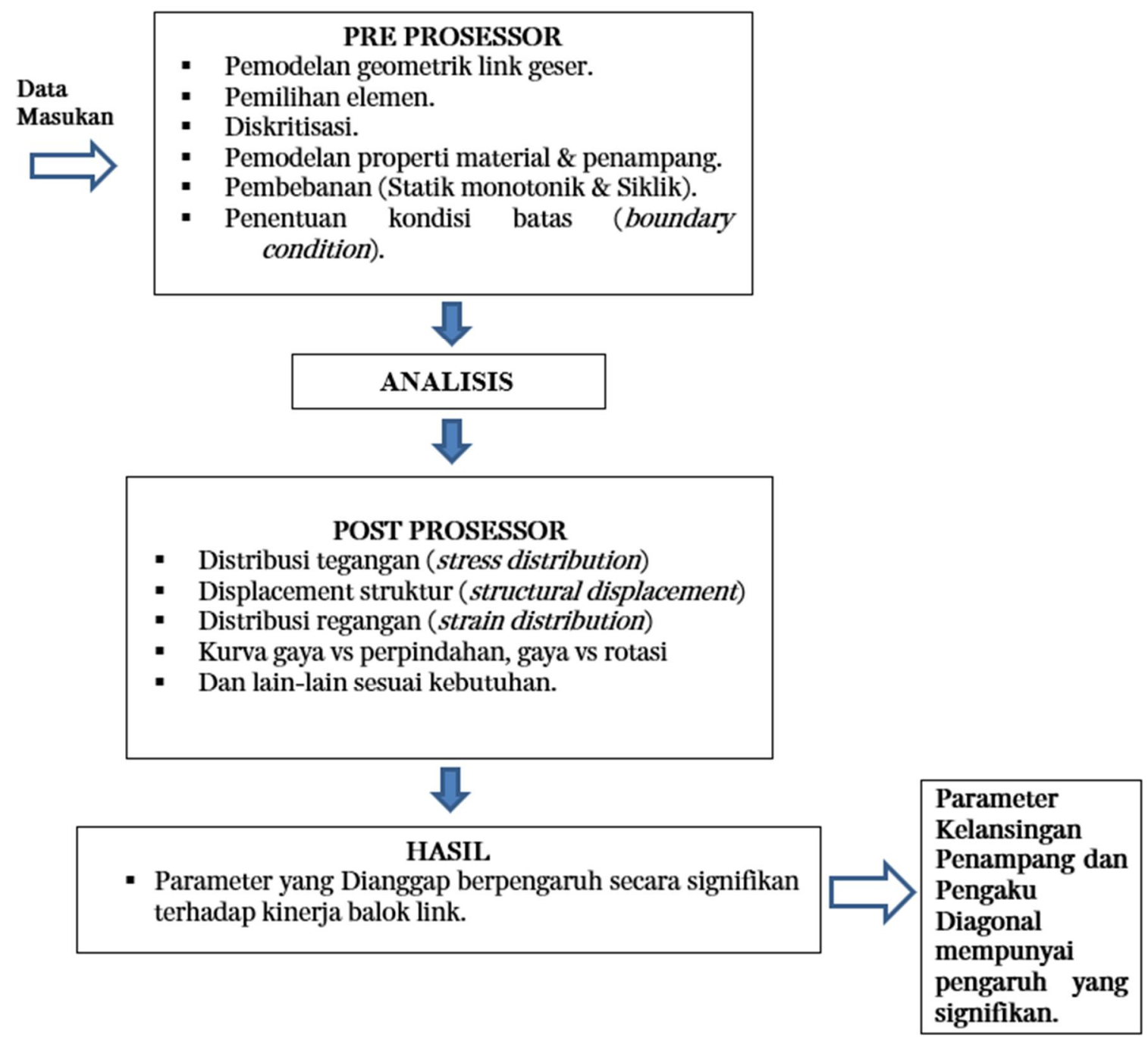

Gambar 3. Bagan Alir Tahapan Analisis Dalam Kajian Numerik

\subsection{Pemodelan Benda Uji Link}

\section{Model benda uji dengan variasi jarak pengaku lateral}

Dalam penelitian ini benda uji link geser dimodelkan dalam beberapa model seperti yang ditunjukkan dalam Gambar 4 dan 5. Gambar 4 adalah model benda uji link geser sesuai standar AISC, Balok profil WF 200.100.5,5.8 panjang $400 \mathrm{~mm}$ dengan 3 buah pengaku (stiffner) dengan ketebalan $6 \mathrm{~mm}$. 


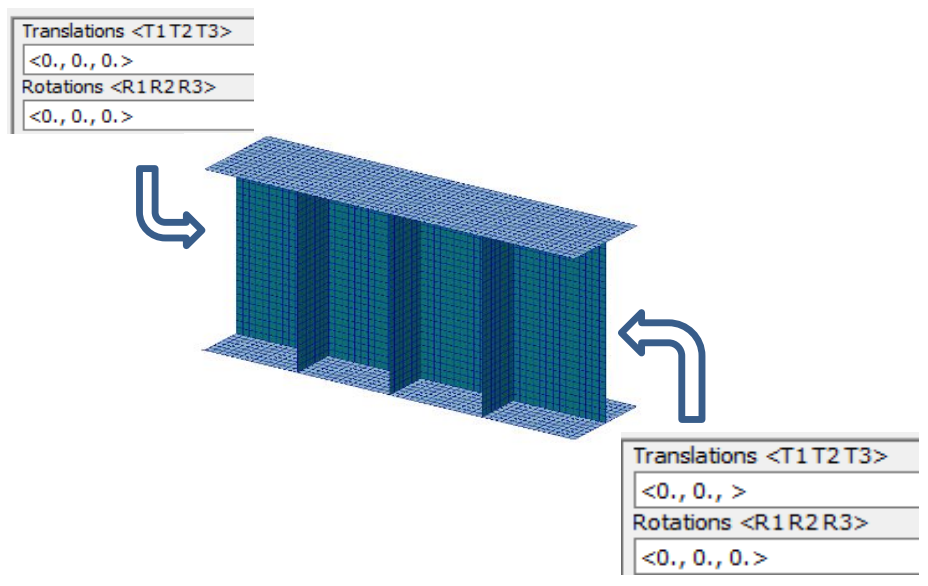

Gambar 4. Model benda uji link dengan kondisi batas tumpuan ujung
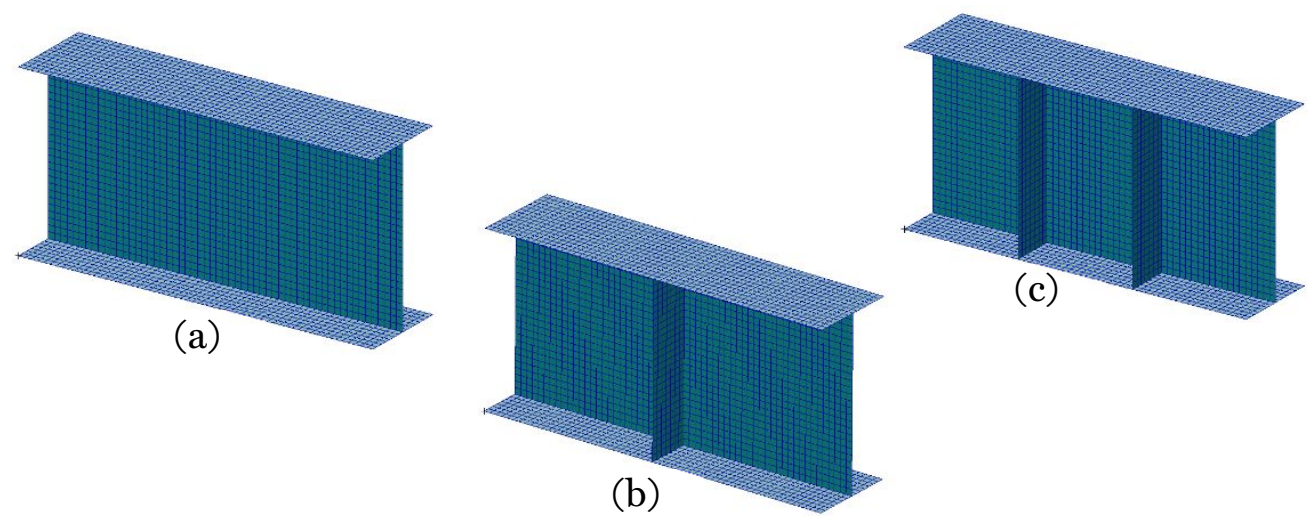

Gambar 5. Model benda uji link dengan variasi jarak pengaku

\section{Model benda uji dengan variasi nilai kelansingan sayap (bf/2tf)}

Model link geser yang dianalisa bentuknya sama dengan yang ditunjukkan dalam Gambar 5.a, tetapi dengan variasi nilai kelansingan sayap ( $\lambda \mathrm{f}=\mathrm{bf} / 2 \mathrm{tf}) 4.17 ; 5$ dan 6,25 .

\section{Model benda uji dengan kombinasi geometrik pengaku}

Model ini merupakan modifikasi dari model yang sebelumnya pada benda uji dibuat 2 buah pengaku pada bagian badan yaitu dalam arah tegak lurus sayap dan pengaku yang dipasang dalam arah diagonal pada bagian badan. Dalam kajian ini digunakan asumsi bahwa pengaku pengaku tersebut selain dapat mencegah terjadinya tekuk lokal juga dapat meningkatkan kekakuan dan kekuatan penampang. Gambar 6.a dan 6.b menunjukkan link dengan kombinasi pengaku lateral dan diagonal, dan link dengan pengaku diagonal saja. 

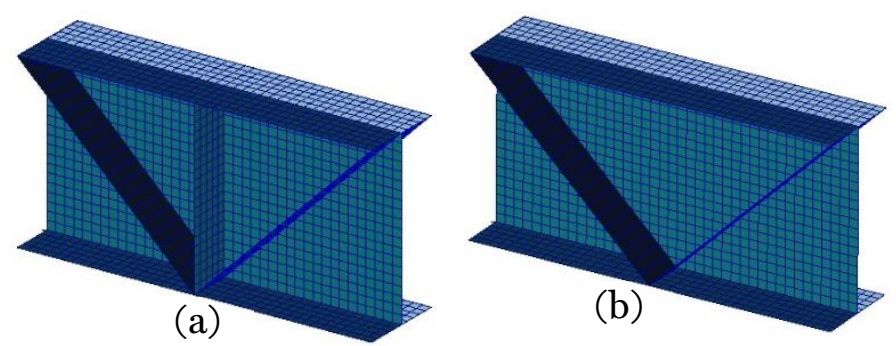

Gambar 6. Model benda uji link geser dengan pengaku diagonal

\subsection{Material}

Data material yang digunakan dalam analisis numerik didapatkan dari hasil uji tarik baja profil 200.100.5,5.8 yang dilakukan di laboratorium / workshop. Data data material yang didapatkan dari hasil uji tarik adalah : Modulus elastisitas E $=200.000 \mathrm{MPa}$, tegangan leleh $(\mathrm{fy})=300 \mathrm{MPa}$ poisson ratio $(\mu)=0,3$. Kurva hubungan tegangan vs regangan dari hasil uji tarik diperlihatkan pada Gambar 7.

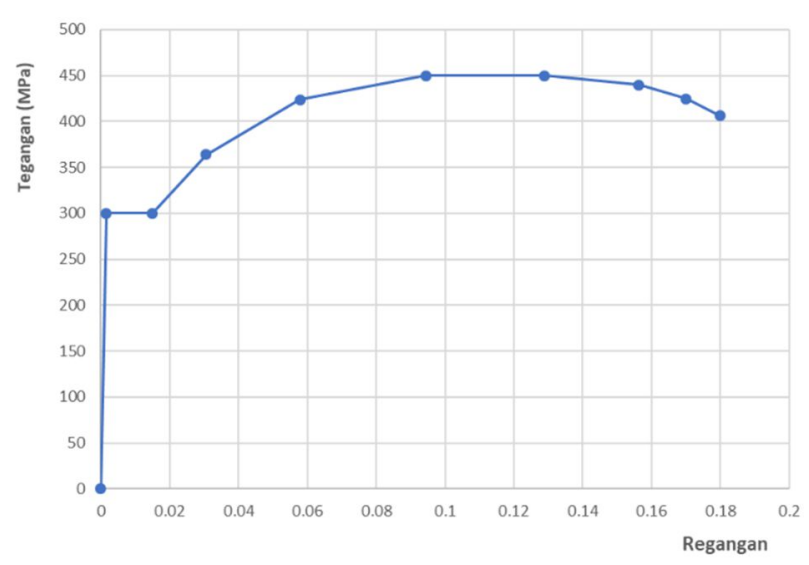

Gambar 7. Kurva tegangan vs regangan material profil WF 200.100.5,5.8

\subsection{Pembebanan}

Pembebanan yang dikenakan pada benda uji dalam bentuk kontrol perpindahan (displacement control) secara bertahap (incremental Untuk mendapatkan nilai nilai parameter kekuatan (strength), kekakuan (stiffness) dan daktilitas pembenanan dilakukan secara static monotonic dengan urutan $5 \mathrm{~mm}, 10 \mathrm{~mm}, 15 \mathrm{~mm}, 20 \mathrm{~mm}, 25 \mathrm{~mm}, 30 \mathrm{~mm}$ dan $36 \mathrm{~mm}$. Hasil analisis dinyatakan dalam bentuk kurva hubungan Beban vs perpindahan. Sedangkan untuk mendapatkan nilai dissipasi energi pembebanan terhadap benda uji dilakukan secara siklik (quasi static), hasil analisis dinyatakan dalam bentuk kurva hysteretic. Luas kurva hystheretic untuk masing masing siklus pembebanan menyatakan besarnya kemampuan benda uji dalam dissipasi energi. Untuk pembebanan siklik nilai perpindahan yang diberikan pada masing masing siklus disesuaikan dengan urutan pembebanan (loading sequence) yang ditetapkan dalam ketentuan AISC 2005 dalam seismic provisions for structural steel buildings, seperti yang ditunjukkan dalam Gambar 8. 


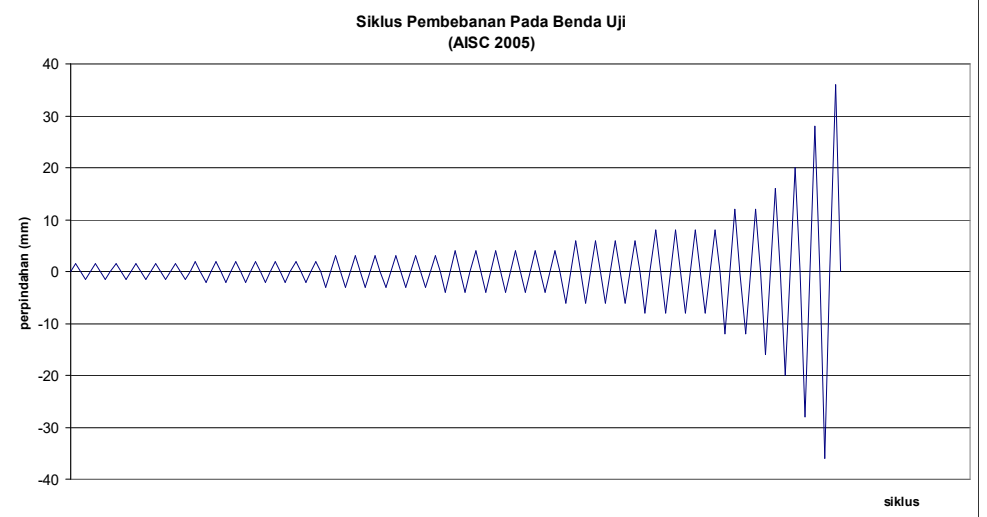

Gambar 8. Pola pembebanan yang digunakan dalam pengujian siklik

\section{HASIL DAN PEMBAHASAN}

\subsection{Pengaruh Variasi Jarak Pengaku}

Pada prinsipnya pengaku yang dipasang pada bagian badan profil WF berfungsi untuk menghambat terjadinya tekuk lokal pada bagian sayap dan badan. Dalam pengujian ini dibuat empat buah model benda uji seperti yang telah ditunjukkan dalam Gambar 4 dan 5 . Kurva beban vs perpindahan pada Gambar 9 memperlihatkan perbandingan perilaku empat buah model benda uji dibawah pembebanan statik monotonik.

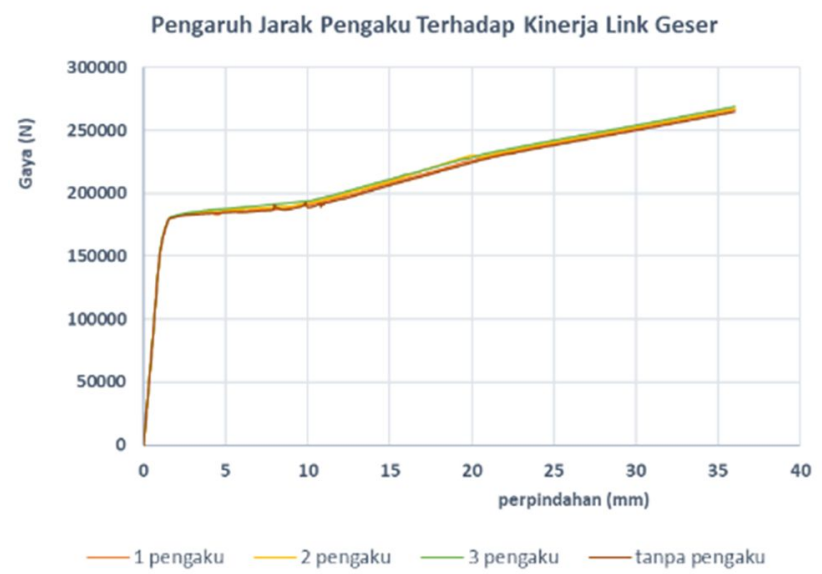

Gambar 9. Pengaruh variasi jarak pengaku

Kurva beban vs perpindahan pada Gambar 9 menunjukkan bahwa variasi jarak pengaku tidak mempunyai pengaruh yang signifikan terhadap kinerja link geser terutama dalam kondisi elastis terlihat bahwa keempat kurva tersebut berimpit satu sama lain. Sedangkan benda uji dengan pengaku menunjukkan kinerja yang lebih baik dalam kondisi inelastis tetapi pengaruhnya tidak begitu signifikan. Gambar 10 memperlihatkan kontur tegangan serta deformasi yang terjadi pada benda uji dalam kondisi awal leleh (initial yield). Leleh pertama (initial yield) terjadi saat beban perpindahan dy $=1 \mathrm{~mm}$, tegangan leleh (fy) sebesar $300 \mathrm{MPa}$ terjadi pada posisi pertemuan sayap dan badan. 


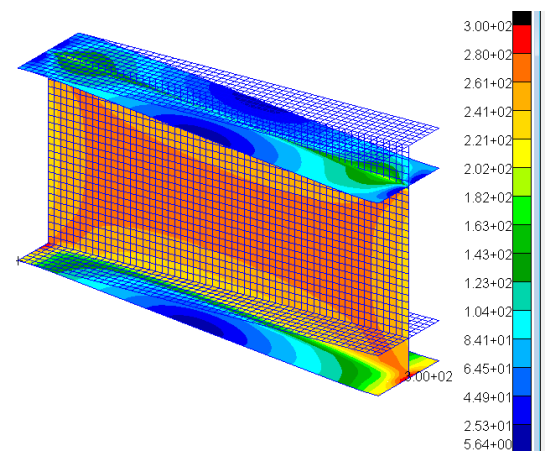

Gambar 10. Initial yield terjadi pada bagian ujung bawah benda uji pada saat beban perpindahan $1 \mathrm{~mm}$.

Nilai nilai daktilitas dan kekakuan elastis untuk benda uji link geser dengan variasi jarak pengaku lateral ditunjukkan dalam Tabel 1.

Tabel 1. Perbandingan Perilaku Link Geser Dengan Variasi Jarak Pengaku

\begin{tabular}{llllllll}
\hline Model & $\begin{array}{l}\text { Jarak } \\
\text { Pengaku }\end{array}$ & $\begin{array}{l}\text { dy } \\
(\mathbf{m m})\end{array}$ & $\begin{array}{l}\text { du } \\
(\mathbf{m m})\end{array}$ & $\begin{array}{l}\text { Py } \\
(\mathbf{N})\end{array}$ & $\begin{array}{l}\text { Pu } \\
(\mathbf{N})\end{array}$ & $\boldsymbol{\mu}$ & $\begin{array}{l}\mathbf{K}_{\text {elast. }} \\
(\mathbf{N} / \mathbf{m m})\end{array}$ \\
\hline TP & & 1 & 36 & 153.045 & 264.774 & 36 & 153.045 \\
\hline P1 & $\mathrm{L} / 2$ & 1 & 36 & 153.263 & 266.764 & 36 & 153.263 \\
\hline P2 & $\mathrm{L} / 3$ & 1 & 36 & 153.529 & 267.622 & 36 & 153.529 \\
\hline P3 & $\mathrm{L} / 4$ & 1 & 36 & 153.818 & 269.159 & 36 & 153.818 \\
\hline
\end{tabular}

Data data pada Tabel 1 memperlihatkan tidak terdapat perubahan yang signifikan terhadap kinerja benda uji dengan perubahan jarak pengaku. Model benda uji TP diperlihatkan pada Gambar 5a, model P1 dan P2 diperlihatkan pada Gambar 5b dan 5c, model P3 pada Gambar 4.

\subsection{Pengaruh kelansingan penampang}

Nilai kelansingan penampang berpengaruh terhadap terjadinya tekuk lokal (local buckling) pada bagian sayap dan bagian badan profil. Dalam penelitian dilakukan pengujian terhadap pengaruh kelansingan sayap dan kelansingan badan terhadap kinerja benda uji (link geser). Model benda uji seperti yang diperlihatkan pada Gambar 4 dengan melakukan variasi terhadap tebal sayap. Kurva beban vs perpindahan pada Gambar 11 memperlihatkan pengaruh kelansingan penampang terhadap perilaku seismik model benda uji link geser. 


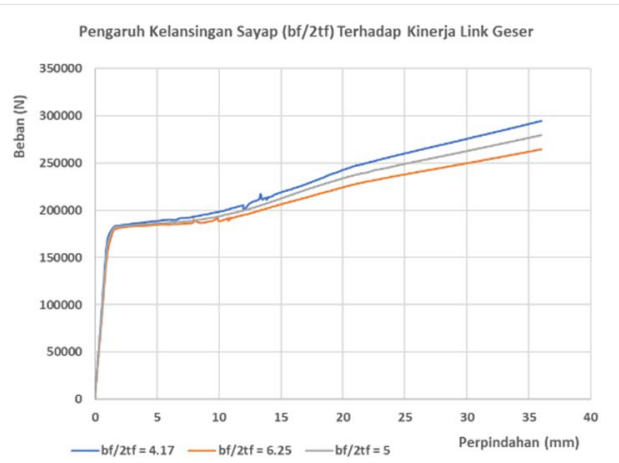

(a)

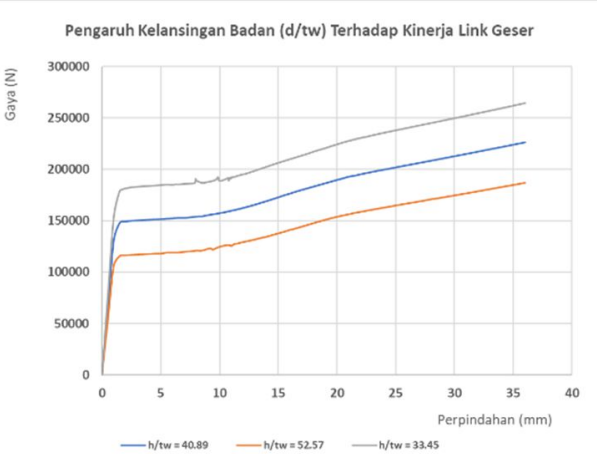

(b)

Gambar 11. Pengaruh kelansingan penampang terhadap kinerja link geser. (a) Kelansingan sayap (b) kelansingan badan

Nilai nilai daktilitas dan kekakuan elastis untuk benda uji link geser dengan variasi nilai kelansingan sayap ditunjukkan dalam Tabel 2.

Tabel 2. Perbandingan Perilaku Link Geser Dengan Variasi Kelansingan Sayap

\begin{tabular}{lllllllll}
\hline Model & $\begin{array}{l}\text { Tebal } \\
\text { sayap } \\
(\mathbf{m m})\end{array}$ & Kelansingan & $\begin{array}{l}\text { dy } \\
(\mathbf{m m})\end{array}$ & $\begin{array}{l}\text { du } \\
(\mathbf{m m})\end{array}$ & $\begin{array}{l}\text { Py } \\
(\mathbf{N})\end{array}$ & $\begin{array}{l}\mathbf{P u} \\
(\mathbf{N})\end{array}$ & $\boldsymbol{\mu}$ & $\begin{array}{l}\mathbf{K}_{\text {elast. }} \\
(\mathbf{N} / \mathbf{m m})\end{array}$ \\
\hline Ld412 & 8 & 6,25 & 1 & 36 & 153.045 & 264.774 & 36 & 153.045 \\
\hline Ld500 & 10 & 5,00 & 1,5 & 36 & 180.869 & 279.669 & 24 & 120.579 \\
\hline Ld417 & 12 & 4,17 & 1,5 & 36 & 182.014 & 294.606 & 24 & 121.343 \\
\hline
\end{tabular}

Tabel 2 memperlihatkan peningkatan kemampuan benda uji dalam menahan beban sementara nilai daktilitas benda uji mengalami penurunan, sementara perilaku benda uji dengan variasi kelansingan badan diperlihatkan dalam Tabel 3.

Tabel 3. Perbandingan Perilaku Link Geser Dengan Variasi Kelansingan badan

\begin{tabular}{lllllllll}
\hline Model & $\begin{array}{l}\text { Tebal badan } \\
(\mathrm{mm})\end{array}$ & Kelansingan & $\begin{array}{l}\text { dy } \\
(\mathbf{m m})\end{array}$ & $\begin{array}{l}\mathbf{d u} \\
(\mathrm{mm})\end{array}$ & $\begin{array}{l}\mathbf{P y} \\
(\mathrm{N})\end{array}$ & $\begin{array}{l}\mathbf{P u} \\
(\mathbf{N})\end{array}$ & $\boldsymbol{\mu}$ & $\begin{array}{l}\mathbf{K}_{\text {elast. }} \\
(\mathbf{N} / \mathbf{m m})\end{array}$ \\
\hline Ld5257 & 3,5 & 52,57 & 1,5 & 36 & 153.045 & 264.774 & 24 & 102.030 \\
\hline Ld4089 & 4,5 & 40,89 & 1,5 & 36 & 180.869 & 279.669 & 24 & 120.579 \\
\hline Ld3345 & 5,5 & 33,45 & 1,0 & 36 & 182.014 & 294.606 & 36 & 182.014 \\
\hline
\end{tabular}

Tabel 3 memperlihatkan peningkatan kemampuan benda uji link dalam menahan beban, daktilitas dan nilai kekakuan elastis.

\subsection{Inovasi Terhadap Geometrik Pengaku}

Penempatan pengaku secara diagonal pada bagian badan profil WF dianggap mampu meningkatan kinerja elemen link (Yurisman, 2010). Ketebalan dan konfigirasi pengaku harus ditentukan sedemikian rupa sehingga tidak terjadi overstrength pada balok yang dapat menyebabkan fraktur pada bagian sayap di posisi tumpuan. Dalam penelitian ini dikaji dua bentuk konfigurasi pengaku diagonal seperti diperlihatkan dalam Gambar 12. 

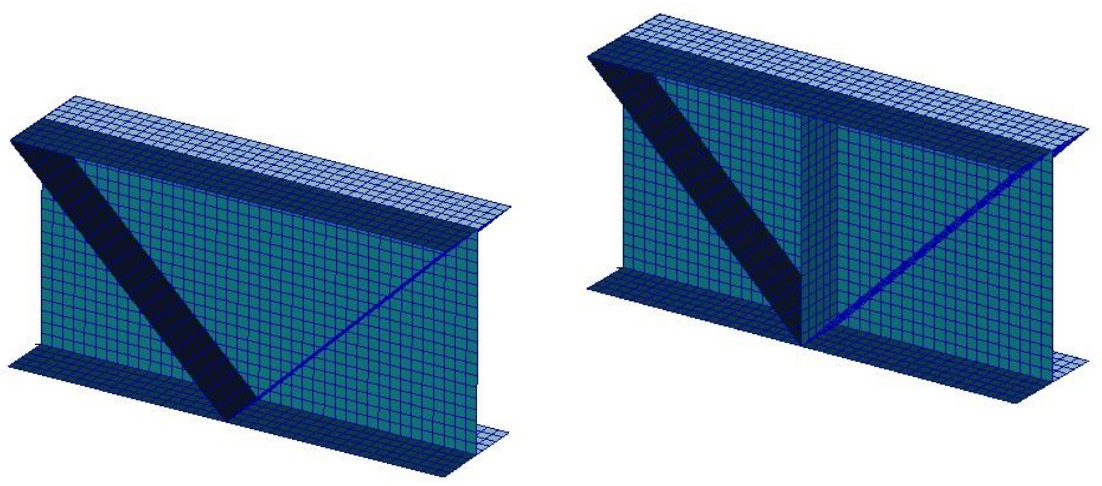

Gambar 12. Link geser dengan pengaku diagonal

Hasil analisis dari kedua model benda uji diperlihatkan pada kurva Gambar 13. Kurva tersebut menunjukkan bahwa perbedaan konfigurasi pengaku tidak berpengaruh terhadap kinerja link yang dihasilkan. Fenomena ini sudah dibuktikan juga pada kurva Gambar 9 yang menjelaskan bahwa pengaku lateral pada bagian badan tidak berpengaruh secara signifikan terhadap kinerja elemen link.

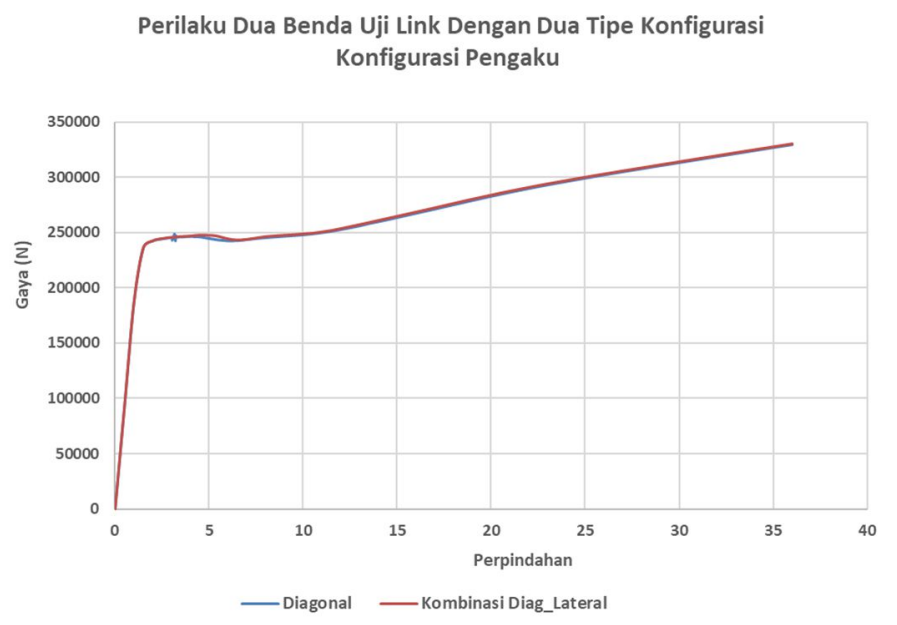

Gambar 13. Perbandingan perilaku dua model konfigurasi pengaku diagonal

Gambar 14 memperlihatkan perilaku kedua benda uji pada kondisi initial yield, dimana bagian pengaku lateral tidak mengalami kelelehan sementara bagian yang lain sudah leleh. Fenomena ini memperkuat anggapan bahwa pengaku lateral pada bagian badan tidak mempunyai konstribusi terhadap peningkatan kinerja benda uji.

Perilaku benda uji pada saat beban maksimum diperlihatkan pada Gambar 15, Gambar tersebut menunjukkan terjadinya tekuk pada bagian pengaku diagonal pada saat perpindahan $36 \mathrm{~mm}$, sementara bagian pengaku vertikal belum mengalami leleh. Pengujian selanjutnya dilakukan dengan model benda uji tanpa pengaku vertikal. Profil yang digunakan tetap mempunyai dimensi yang sama dengan model sebelumnya. Variasi ketebalan pengaku diagonal yang digunakan $3 \mathrm{~mm}, 5 \mathrm{~mm}$ dan $7 \mathrm{~mm}$. Kurva beban vs perpindahan pada Gambar 16 memperlihatkan hasil analisis 3 buah model benda uji dengan variasi ketebalan pengaku diagonal $3 \mathrm{~mm}, 5 \mathrm{~mm}$ dan $7 \mathrm{~mm}$. 

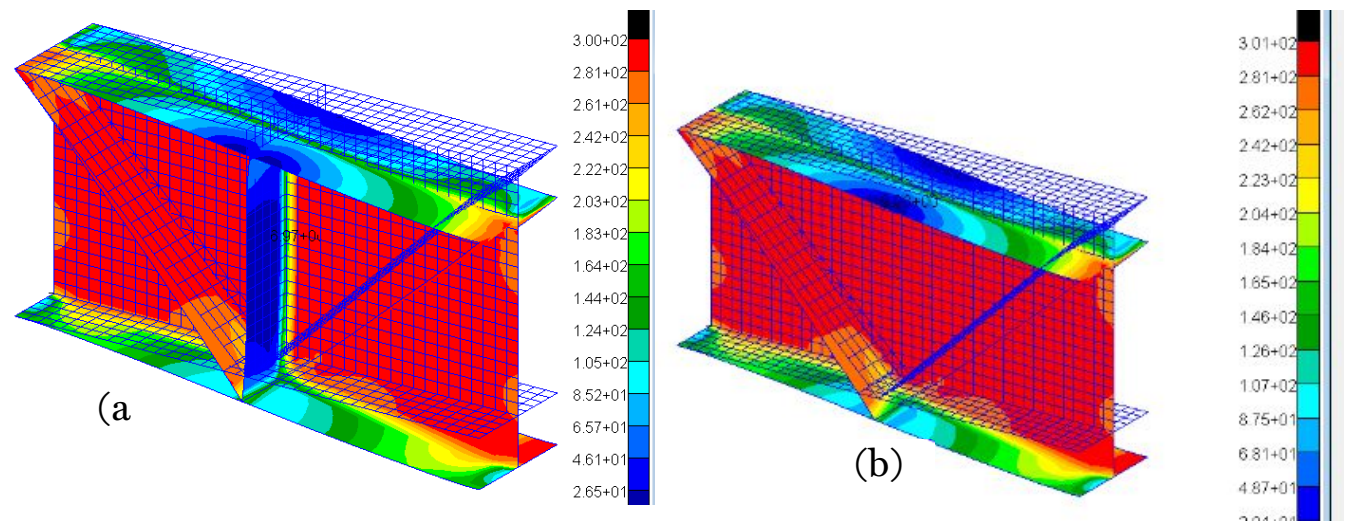

Gambar 14. Perbandingan perilaku dua model konfigurasi pengaku diagonal pada kondisi initial yield
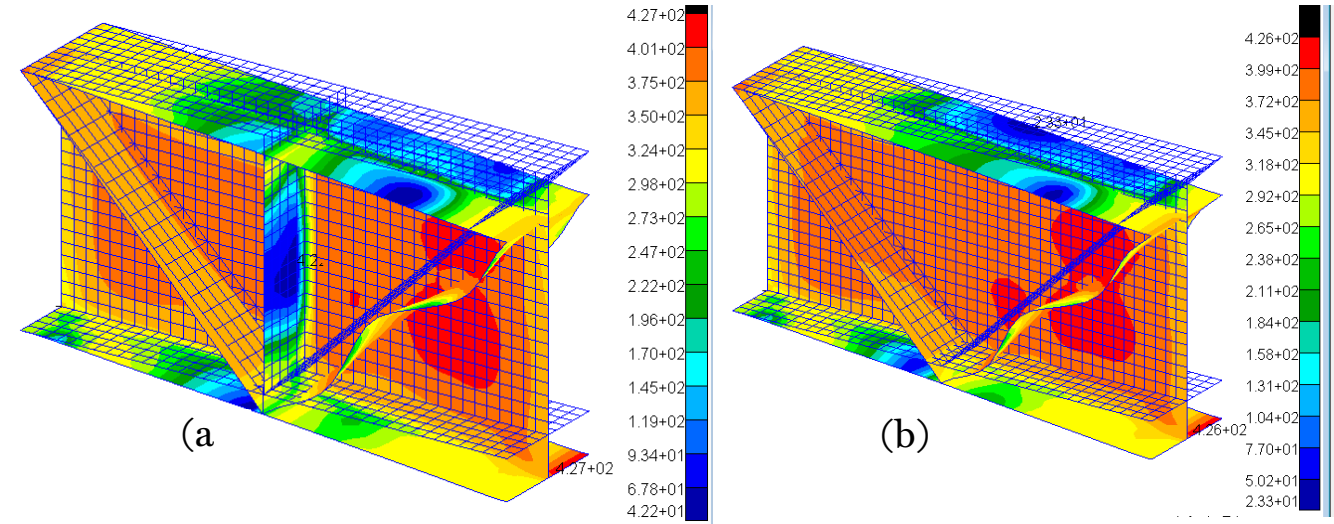

Gambar 15. Perbandingan perilaku dua model konfigurasi pengaku diagonal pada kondisi beban maksimum.

Kurva beban vs perpindahan pada Gambar 16 memperlihatkan perbandingan kinerja yang cukup signifikan dari tiga benda uji link geser dengan variasi ketebalan pengaku diagonal, terutama dari segi kemampuan benda uji dalam menahan beban lateral. Fenomena ini membuktikan hipotesis bahwa pemasangan pengaku diagonal disamping menghambat terjadinya tekuk lokal juga dapat meningkatkan kemampuan penampang dalam menahan beban lateral. Nilai nilai daktilitas dan kekakuan elastis untuk benda uji link geser dengan variasi ketebalan pengaku diagonal ditunjukkan dalam Tabel 4. Tabel 4 menunjukkan bahwa penambahan ketebalan pengaku diagonal berakibat kepada peningkatan kemampuan benda uji dalam menahan beban lateral namun tidak menambah nilai daktilitas.

Tabel 4. Perbandingan Perilaku Link Geser Dengan Variasi Ketebalan Pengaku Diagonal

\begin{tabular}{llllllll}
\hline Model & $\begin{array}{l}\text { Tebal } \\
\text { Pengaku }(\mathrm{mm})\end{array}$ & $\begin{array}{l}\text { dy } \\
(\mathrm{mm})\end{array}$ & $\begin{array}{l}\mathbf{d u} \\
(\mathrm{mm})\end{array}$ & $\begin{array}{l}\text { Py } \\
(\mathrm{N})\end{array}$ & $\begin{array}{l}\text { Pu } \\
(\mathbf{N})\end{array}$ & $\begin{array}{l}\text { (daktilitas) } \\
\boldsymbol{\mu}\end{array}$ & $\begin{array}{l}\mathbf{K}_{\text {elast. }} \\
(\mathbf{N} / \mathbf{m m})\end{array}$ \\
\hline D3 & 3 & $1.5(\mathrm{web})$ & 36 & 235.944 & 329.071 & 24 & 157.296 \\
\hline D5 & 5 & $1,5(\mathrm{web})$ & 36 & 268.695 & 377509 & 24 & 179.130 \\
\hline D7 & 7 & $1,5(\mathrm{web})$ & 36 & 295.975 & 425.060 & 24 & 197.317 \\
\hline
\end{tabular}




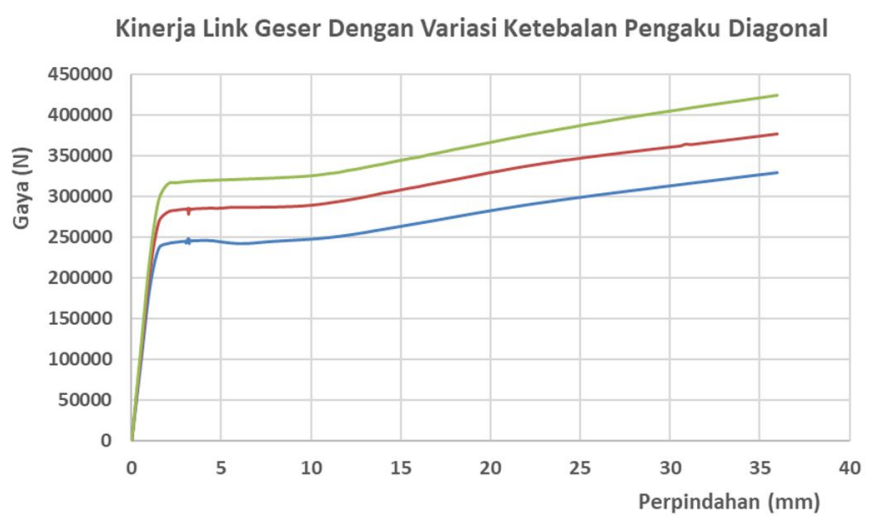

Gambar 16. Perbandingan perilaku tiga model benda uji link geser dengan variasi ketebalan pengaku diagonal.

\subsection{Dissipasi Energi}

Kemampuan dissipasi energi merupakan salah satu parameter penting dalam mengukur kinerja struktur dalam menahan gaya gempa yang masuk pada struktur. Dalam sistem struktur baja tahan gempa tipe EBF, dissipasi energi gempa terjadi melalui proses plastifikasi pada elemen link. Nilai dissipasi energi didapatkan dari kurva hystheretic yang menyatakan hubungan gaya vs perpindahan. Kurva hystheretic didapatkan dari hasil pengujian dari pola pembebanan siklik yang bisa dilakukan secara numerik atau melalui pengujian eksperimental. Protokol pembebanan siklik yang digunakan dalam penelitian ini mengacu pada protokol pembebanan yang ditetapkan oleh standard AISC 2005 seperti yang ditunjukkan dalam Gambar 8. Pengujian dengan pola pembebanan siklik dilakukan terhadap benda uji : model P3 (link standar AISC), D3 (link dengan tebal pengaku diagonal $3 \mathrm{~mm}$ ), D5 (ketebalan pengaku diagonal $5 \mathrm{~mm}$ ) dan D7 (ketebalan pengaku diagonal $7 \mathrm{~mm}$ ). Kurva hysteretic yang diperlihatkan pada Gambar 17 secara umum memperlihatkan bahwa benda uji dengan pengaku diagonal mempunyai kapasitas dissipasi energi yang lebih besar dibandingkan dengan link standar yang biasa digunakan. Kemampuan dissipasi energi juga semakin bertambah dengan penambahan ketebalan pengaku. Namun peningkatan kekuatan yang sangat besar bisa menyebabkan terjadinya overstrength pada elemen link, dimana link tidak lagi merupakan bagian yang terlemah pada system struktur EBF. Oleh karena itu perlu diperhitungkan peningkatan semua parameter tersebut secara optimal.

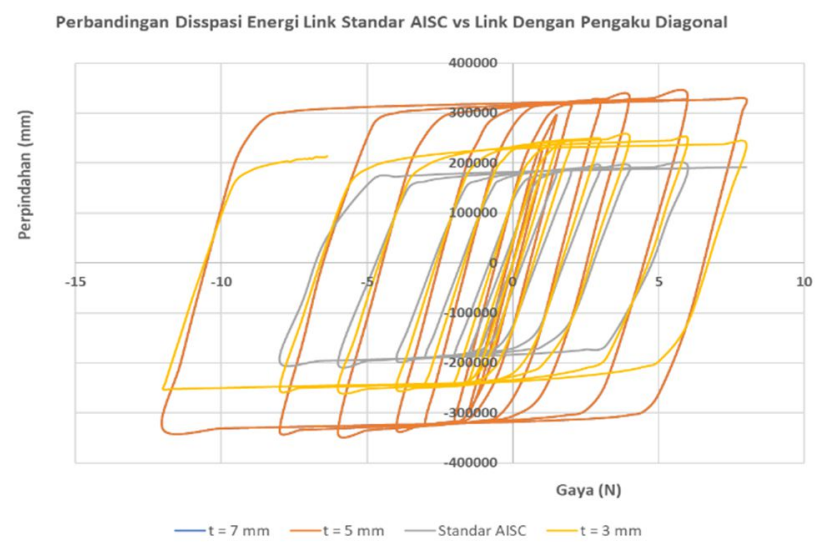

Gambar 17. Kurva hysteretic perbandingan kemampuan dissipasi energi link standar dengan link yang menggunakan pengaku diagonal 


\section{KESIMPULAN}

Kinerja suatu sistem struktur tahan gempa dapat diukur berdasarkan kemampuan struktur dalam melakukan dissipasi terhadap energi gempa (seismic) yang masuk pada struktur. Parameter parameter penting yang terkait dengan hal tersebut adalah kekuatan, kekakuan, daktilitas dan nilai dissipasi energi. Nilai kekuatan, kekakuan dan daktilitas seperti yang ditunjukkan dalam Tabel 1, 2, 3 dan 4, sedangkan kemampuan benda uji dalam dissipasi energi tergambar pada luasan kurva hysteretic yang dihasilkan dengan pembebanan siklik. Berdasarkan hasil kajian secara numerik terhadap beberapa parameter seismik yang dianggap berpengaruh terhadap kinerja link geser dapat disimpulkan sebagai berikut :

1. Spasi / jarak antar pengaku lateral yang dipasang pada bagian badan link tidak mempunyai pengaruh yang signifikan terhadap perilaku seismik link seperti yang diperlihatkan pada kurva Gambar 9.

2. Nilai variasi kelansingan penampang profil IWF dalam kondisi pembenanan static monotonik cukup berpengaruh terhadap kinerja link, hal ini dapat dibuktikan dengan perubahan terhadap nilai kemampuan link dalam menahan gaya lateral, nilai daktilitas serta nilai kekakuan elastis seperti yang diperlihatkan dalam Tabel 1, 2, 3 dan 4 .

3. Pemasangan plat pengaku secara diagonal pada bagian badan elemen link mempunyai pengaruh yang sangat signifikan terhadap perilaku seismik / kinerja link terutama dalam kemampuan dissipasi energi, hal ini dapat dibuktikan dari kurva hystheretic hasil analisis dengan pembebanan siklik pada Gambar 17.

4. Ketebalan plat pengaku yang dipasang secara diagonal pada bagian badan perlu diperhitungkan agar tidak terjadi kelebihan kekuatan (overstrength) pada elemen link, sehingga link tetap berfungsi sebagai elemen yang paling lemah (sekring) pada sistem struktur EBF.

\section{UCAPAN TERIMAKASIH}

Ucapan terima kasih yang sebesar besarnya kepada Pusat Penelitian dan Pengabdian Kepada Masyarakat Politeknik Negeri Padang yang telah mendanai penelitian ini dengan dana DIPA PNP tahun anggran 2021 (Kontrak No.356/PL9.15/P6/2021 tanggal 21 Mei 2021). Semoga hasil penelitian ini bermanfaat bagi mahasiswa, staf pengajar terkait dengan bidangnya umumnya untuk pengembangan ilmu pengetahuan dalam bidang sistem struktur baja tahan gempa.

\section{DAFTAR PUSTAKA}

American Institute of Steel Construction. (2005). Seismic Provision for Structural Steel Building. AISC, Inc.

Chacón, R., Vega, A., \& Mirambell, E. (2019). Numerical study on stainless steel I-shaped links on eccentrically braced frames. Journal of Constructional Steel Research, 159, 67-80. https://doi.org/https://doi.org/10.1016/j.jcsr.2019.04.014

Engelhardt, M. D., \& Popov, E. P. (1992). Experimental performance of long links in eccentrically braced frames. Journal of Structural Engineering, 118(11), 3067-3088. https://doi.org/https://doi.org/10.1061/(asce)0733-9445(1992)118:11(3067)

Ghobarah, A., \& Ramadan, T. (1991). Seismic analysis of links of various lengths in eccentrically braced frames. Canadian Journal of Civil Engineering, 18(1), 140-148.

Kasai, K., \& Popov, E. P. (1986). Cyclic web buckling control for shear link beams. Journal of Structural Engineering, 112(3), 505-523. https://doi.org/https://doi.org/10.1061/(asce)07339445(1986)112:3(505) 
Kurdi, K., Budiono, B., Moestopo, M., Kusumastuti, D., \& Muslih, M. R. (2017). Residual stress effect on link element of eccentrically braced frame. Journal of Constructional Steel Research, 128, 397-404. https://doi.org/https://doi.org/10.1016/j.jcsr.2016.09.006

Malley, J. O., \& Popov, E. P. (1984). Shear links in eccentrically braced frames. Journal of Structural Engineering, 110(9), 2275-2295. https://doi.org/https://doi.org/10.1061/(asce)07339445(1984)110:9(2275)

Ricles, J. M., \& Popov, E. P. (1989). Composite action in eccentrically braced frames. Journal of Structural Engineering, 115(8), 2046-2066. https://doi.org/https://doi.org/10.1061/(asce)0733-9445(1989)115:8(2046)

Volynkin, D., Dusicka, P., \& Clifton, G. C. (2019). Intermediate web stiffener spacing evaluation for shear links. Journal of Structural Engineering, 145(2), 4018257. https://doi.org/https://doi.org/10.1061/(asce)st.1943-541x.0002244

Yurisman, Y., Budiono, B., Moestopo, M., \& Suarjana, M. (2010a). Behavior of Shear Link of WFSection with Diagonal Web Stiffener of Eccentrically Braced Frame (EBF) of Steel Structure. Journal of Engineering and Technological Sciences, 42(2), 103-128. https://doi.org/https://doi.org/10.5614/itbj.eng.sci.2010.42.2.1

Yurisman, Y., Budiono, B., Moestopo, M., \& Suarjana, M. (2010b). Kajian Numerik Terhadap Kinerja Link Geser dengan Pengaku Diagonal pada Struktur Rangka Baja Berpenopang Eksentrik $\begin{array}{llllll}\text { (EBF). Jurnal Teknik } & \text { Sipil } & \text { ITB, } & \text { 17 (1), } & \text { 25-38. }\end{array}$ https://doi.org/https://doi.org/10.5614/jts.2010.17.1.3 